\title{
Hybridity and the search for the right mix in governing PPP collaboration
}

Erik Hans Klijn, Joop Koppenjan, and Rianne Warsen (Erasmus University Rotterdam, Department of Public Administration and Sociology)

Publiced in: Meek, J. W. (Ed.). (2021). Handbook of Collaborative Public Management. Cheltenham/Northhampton Ma: Edward Elgar Publishing, pp.113-128

\begin{abstract}
Public-private partnerships are a vehicle used a lot by governments all around the world. When it was introduced the idea relied a lot on economic reasoning in which contracts, monitoring and performance criteria were important to achieve results. But from the beginning PPP's were a hybrid idea because there were also assumptions about collaborations and synergy that fused the idea. In this chapter we explore the ideas behind PPP, the importance of collaboration to make PPP's work and we show, with recent research results, that PPP's actually need a mix of contracts and collaboration to work.
\end{abstract}

Keywords: Public private partnerships, collaboration, performance, contractual governance, relational governance 


\section{Authors}

Erik Hans Klijn (Orcid id: 0000-0002-2121-6818) is professor of Public Administration at the Department of Public Administration and Sociology, Erasmus University Rotterdam (The Netherlands). He published in various journals on governance networks, complex decision-making and network management and media attention and branding.

Recent publications:

- $\quad$ Klijn, E.H., I. van Meerkerk, J. Edelenbos (2020), How do network characteristics influence network managers' choice of strategies, Public Money and management. Vol 40(2): 149-159

- $\quad$ Nederhand, J. Klijn, E.H. (2019), Stakeholder involvement in public private partnerships Its influence on the innovative character of projects and on project performance. Administration and Society vol51(8): 1200-1226

- $\quad$ Lewis, J. L. Ricard, E.H. Klijn (2018). How innovation drivers, networking and leadership shape public sector innovation capacity, International Review of Administrative Science (IRAS), Vol. 84(2) 288-307

Joop Koppenjan (Orcid id: https://orcid.org/0000-002-0091-5760) is professor of Public Administration at the Erasmus University Rotterdam. His research topics include public policy, policy networks, public private partnerships and public management, with a focus on governance, stakeholder involvement, public values and sustainability. Areas of application are infrastructurebased sectors such as transport, water, and energy, and social sectors such as social support, care, and safety.

Recent publications:

- Koppenjan, J.F.M., P.M. Karre and C.J.A.M. Termeer (eds.) (2019) Smart Hybridity. Potentials and Challenges of New Governance Arrangements. The Hague: Eleven international Publishing;

- $\quad$ Mu, R., M. de Jong, M., and J.F.M. Koppenjan, J.F.M. (2019), Assessing and Explaining Interagency Collaboration Performance: A Comparative Case Study of Local Governments in China, Public Management Review, vol 21, nr 4.; and

- Hueskes, M., J.F.M. Koppenjan and S. Verweij (2019). Public-private partnerships for infrastructure: Lessons learned from Dutch and Flemish PhD-theses in: European Journal of Transport Infrastructure and Research, 19(3), pp. 160-176.

Rianne Warsen (Orcid id: https://orcid.org/0000-0003-2690-2726) is an Assistant Professor of Public Management at the Department of PublicAdministration and Sociology at the Erasmus University Rotterdam, the Netherlands. Her research focuses on public-private partnerships, collaborative governance and the dynamics between contractual and relational aspects in public-private collaborations. She has a strong background in various research methods, in particular qualitative methods such as Qualitative Comparative Analysis (QCA) and Q-methodology.

Recent publications:

- Warsen, R., Greve, C., Klijn, E.H., Koppenjan, J.F.M., Siemiatycki, M. (2020). How do professionals perceive the governance of public-private partnership? Evidence from Canada, the Netherlands and Denmark. Public Administration. 98: 124-139

- Warsen, R., Klijn, E.H., Koppenjan, (2019). Mix and Match: How Contractual and Relational Conditions Are Combined in Successful Public-Private Partnerships. Journal of Public Administration and Theory (JPART) Volume 29, Issue 3, July 2019, Pages 375-393

- Warsen, R. J. Nederhand, E.H. Klijn, S. Grotenbreg, J.F.M. Koppenjan (2018) What makes public-private partnerships work? Survey research into the outcomes and the quality of cooperation in PPPs. Public Management Review. VOL. 20, NO. 8, 1165-1185 



\section{INTRODUCTION: THE COLLABORATIVE CHALLENGE OF PUBLIC-PRIVATE PARTNERSHIPS}

Beyond any doubt, public-private partnership (PPP) has become established as an important vehicle to realize infrastructure projects and public services, not only in governmental rhetoric, but also in daily governmental practice. In many countries, governments have turned to the idea of PPPs, or partnerships in general, as an effective way to realize better policy outcomes or to enhance investments in fields like infrastructure, health, or even social policy (Hodge, Greve, \& Boardman, 2010). One of the core elements in PPP is the collaboration between parties from the public and the private domain. Governments aim to realize public infrastructures and services for the common good but have limited budgets and struggle with planning and managing complex projects, and private parties often have access to private funds, have expertise regarding the design and development of large infrastructure, and are better able to mitigate risks and manage large projects (Hodge \& Greve, 2005).

\section{Collaboration and PPP}

PPP aims to realize collaboration between public and private actors in which they both commit their resources and capabilities to the realization of a common objective, such as the co-production of a public good or a public service and the public infrastructure that is required for this service (Klijn \& Teisman, 2003). Collaboration then is defined as the joint action of two or more actors to align their activities, pool their resources, and achieve shared goals (see e.g. Huxham \& Vangen, 2005; Keast, Brown, \& Mandell, 2007).

However, collaboration between governments and private parties is far from selfevident. Governments pursue the common good but are bound by regulations and bureaucratic procedures, and, as a consequence of the democratic electoral cycle, they have a relatively short time perspective. In contrast, private parties are profit driven and require a longer-term perspective to be able to invest and get a return on investment. PPPs are of a hybrid nature. They bring together parties with different objectives, goals, and institutional logics, which are hard to align (Jacobs, 1992; Klijn \& Teisman, 2003). This raises the question of how collaboration can be achieved in these hybrid PPPs and which governance mechanisms can be applied to accomplish commitment to a collaborative effort to realize public goals, products, or services. Thus, our aim in this chapter is to:

- discuss the basic theoretical underpinnings of PPPs and elaborate the importance of collaboration in the functioning of PPPs (second and third sections),

- take a closer look at the governance mechanisms that are in place in PPPs (third section) and evaluate their significance using recent empirical results from a large research project in which we have been involved within the last five years (fourth section),

- discuss the consequences of our empirical findings regarding the hybrid nature of the governance of collaboration in PPPs (fifth section). 


\section{PPP and Its Governance Modes}

PPPs can be roughly defined as a "more or less sustainable cooperation between public and private actors in which joint products and/or services are developed and in which risks, costs and profits are shared" (Klijn \& Teisman, 2003, p. 137). Many different forms of public-private collaboration come under this heading. So, in the next section, we present a classification of public-private relationships and collaborations in order to position Design, Build, Finance, Maintain (DBFM), and Design, Build, Finance, Maintain, and Operate (DBFMO) contracts vis-à-vis other forms of PPPs. DBFM(O) contracts have become the dominant model of public infrastructure provision in many parts of the world and are central in the rest of our contribution.

Next, we address the theoretical ideas underlying PPPs and the extent to which they succeed in realizing collaboration. In doing so, we argue not only that PPPs are hybrid in an empirical sense, but also that the theoretical body of knowledge underlying this phenomenon is of a hybrid nature. As a result, depending on the context, different governance logics are deemed as most appropriate regarding the governance of collaboration within PPPs. Most of the literature makes a distinction between contractual governance (steering achieved by contracts) and relational governance (steering using relational qualities like communication, conflict management, trust, and so on). To a certain extent, these governance logics may complement each other, but they are based on fundamentally different and contradictory theoretical assumptions and mechanisms. In practice, this may result in confusing, ineffective, and problematic governance hybrids. Therefore, the question that guides this contribution is how the respective governance mechanisms - contracts versus trust and management contribute to the realization of collaboration in PPPs, and, more specifically, how they relate to each other and how they can be combined. In this contribution, we provide empirical evidence that suggests that neither of these governance mechanisms is sufficient on its own and that, in essence, the governance of collaboration entails finding the right mix of governance modes.

\section{FORMS OF PUBLIC-PRIVATE PARTNERSHIPS}

In the literature on PPPs, two main dimensions underlying the various types of partnership can be distinguished (see Hodge \& Greve, 2005; Osborne, 2000):

1. The (formal) organization of the partnership: to what degree is the partnership organized in a strongly formalized form (like a contract or a newly set up organization) or in a more loosely coupled cooperation (like a network)?

2. The nature of the relationship between the public and the private actors: is it a more or less horizontal relationship between equal partners, a principal to principal relation, or a principal-agent relationship, in which the principal (government) acts as the client that commissions an agent (private contractor) to execute a task, project, or service.

When these two dimensions are combined (see Table 1), an overview of possible public-private relationships appears. Only forms 3 and 4 are actually considered in most literature as real PPP forms, but the table provides an overview of possible collaborations between public and private organizations 
Table 1: A typology of forms of public-private relationships

\begin{tabular}{|l|l|l|}
\hline Type of relation & Principal-agent relation & $\begin{array}{l}\text { Principal-principal relation } \\
\text { (partnership) }\end{array}$ \\
\hline Lrganizational form & $\begin{array}{l}\text { 1. Interaction between public } \\
\text { and private actors in } \\
\text { implementing governmental } \\
\text { policies and providing public } \\
\text { services. Limited } \\
\text { collaboration. Governments } \\
\text { determine objectives and } \\
\text { conditions for implementation. }\end{array}$ & $\begin{array}{l}\text { 2. Network-like partnerships in } \\
\text { developing policies, planning, } \\
\text { or coordinating activities. } \\
\text { Loosely coupled collaboration. } \\
\text { Examples: preventive health } \\
\text { networks for obesity, area } \\
\text { development, or other networks } \\
\text { where public and (semi-)private } \\
\text { actors work together on more or } \\
\text { less equal terms. }\end{array}$ \\
\hline $\begin{array}{l}\text { Tight organizational } \\
\text { form }\end{array}$ & $\begin{array}{l}\text { 3. Design, Build, Finance, } \\
\text { Maintain, (Operate) contracts. } \\
\text { Collaboration is to a large } \\
\text { extent determined by the } \\
\text { contract. }\end{array}$ & $\begin{array}{l}\text { 4. Consortium: Partners form a } \\
\text { new organizational entity that } \\
\text { implements a service or product } \\
\text { (like Urban Regeneration } \\
\text { Companies). }\end{array}$ \\
\hline
\end{tabular}

Source: Adapted from Klijn (2010)

The first type of PPP is characterized by a loosely coupled arrangement and a principal-agent relationship. This concerns relationships in which public actors involve private actors to provide services or policy outcomes that match the government's goals and aims, including private actors' implementation actions that fit in policy programs. The relation between private schools and public actors, where public actors support private schools and private schools provide services that fit public goals, is a relevant example (see for instance Weihe, 2008). One could question whether this type of relationship can be considered to be a PPP, because it is hardly a concrete partnership, but there are authors who consider this to be one (see the policy approach as discussed by Weihe, 2008). Activities, resources, and objectives are aligned only to a certain extent, as this type of relationship concerns policy implementation. Collaboration is therefore assumed to be limited.

The second type of PPP refers to principal-principal relations with a loosely coupled organization form. This type of PPP has a network-like character with intense interaction between public and private actors in a weakly developed institutional setting and becomes more firmly arranged only by either a contract or an organizational form of partnership in implementing activities. It can be found in complex and enduring processes of development and decision making in urban restructuring. Despite the horizontal nature of these relationships, collaboration challenges still arise, as objectives and institutional logics are not necessarily aligned. Collaboration and its governance in this type of relationship are supposed to resemble networks and collaborative governance as discussed in the literature (Ansel \& Gash, 2008; Kickert, Klijn, \& Koppenjan, 1997).

The third type of partnership is characterized by a tight, contractual organization form and a principal-agent relationship. Projects are often governed by a long-term infrastructure contract, such as a DBFM(O) contract, which is a well-known example of this form. These PPPs are inspired by the Private Finance Initiative (PFI) in the UK that gained popularity 
from the 1980s onwards. In the PFI context, long-term, integrated contracts were developed, and, with the help of these contracts, public actors tendered out the design, building, financing, maintenance, and possibly the operating of a public project to a private consortium. The classic example of this form is the Dartford Crossing over the Thames, which is financed with user fees (Hodge et al., 2010). The idea is that shifting the financial risk to the private consortium will create strong incentives to deliver and maintain the project within time, budget, and scope. The integrated nature of the contract motivates the private consortium to take the full lifecycle into account when designing the project. This allows for innovative solutions and the realization of efficacy gains, thus creating added value. The extended contract periods (20, 25 years, and more) allow the private parties to recoup their investments. Collaboration between public and private parties in this type of PPP is strongly regulated by a contract, and some theories suggest that actual collaboration is hardly necessary as the contract arranges everything (see Williamson, 1996) that is necessary. Other authors have stressed that, in the implementation phase of such relationships, contract parties may develop governance modes that stimulate collaboration and partnership relationships that go beyond simply implementing the contract (see Warsen, Klijn, \& Koppenjan, 2019; Weihe, 2008).

The fourth type of PPP encompasses principal-principal relationships between public and private actors that jointly create and fund a separate organizational form, like a joint public-private venture. This type of PPP is often referred to as an institutional public-private partnership (or alliance). Examples include the urban regeneration companies (see Kort \& Klijn, 2011; ODPM, 2004) that are emerging in various countries. Here, intensive interactions occur between the two partners that jointly develop and organize projects, services, or policies. In doing so, they share a common goal (or at least a set of goals) and associated benefits and risks. Such partnerships are often referred to as 'real' partnerships in which public and private partners really collaborate and can be distinguished from the third type of PPP, in which PPPs are often regarded as a way of contracting out.

\section{PPP AS A THEORETICAL HYBRID: GOVERNANCE LOGICS UNDERLYING PPP}

Besides confusion about the nature of PPPs, different implicit assumptions can be found in the literature about the mechanisms that make PPPs result in collaboration and realize collaborative advantages: for example, projects and services that are realized with private budgets, within time and budget, that are innovative and have added value (Ghobadian et al., 2004; Hodge \& Greve, 2005; Savas, 2000). The key partnership mechanism in PPPs is that private parties are involved earlier and more intensively in the decision-making process than is the case with more traditional client-supplier or principal-agent relationships. The way in which this should be done and the assumptions about how this improves collaboration and outputs are quite different in the available literature, because the PPP concept is a hybrid idea. The PPP idea contains assumptions from two major theoretical perspectives in public administration: New Public Management (NPM) and network and collaborative governance.

On the one hand, one can recognize ideas from NPM that have become dominant in public administration since the 1980s as a reaction to flaws of the Weberian Traditional Public Administration (TPA) (see Hughes, 2012). NPM is about the application of ways of organizing and managing that are common in the private sector to the public sector in order to enhance the performance, efficiency, and transparency of public organizations. In these ideas, governments should focus on the formulation of public policy and leave the implementation to other bodies (agencies at arms-length, private organizations, or non-profit organizations) 
(Osborne \& Gaebler, 1992). A separation between policy formulation and policy implementation should be encouraged by privatization, outsourcing, agentification, and a stronger emphasis on market mechanisms and the involvement of private actors (Hood, 1991). Public actors should control implementation by competition, contracts, and the use of performance indicators and performance measurement. This debate on PPP is strongly inspired by ideas from NPM (Greve, 2007; Nao, 2002). Often, in this debate, the contractual character of PPP is stressed. Various phases of a project, like the design, building, financing, maintenance, and commercial operation of a public road or a public building like a school, hospital, prison, or governmental office are integrated into one contract (DBFM(O) contract), with the aim of realizing a lifecycle approach. The added value lies in the lower costs of coordination between the various components (often expressed as efficiency or value-formoney gains) and in the realization of design optimizations aimed at realizing innovations that reduce costs in the building, maintenance, and operation phases. The consortium can, for instance, use more sustainable (expensive) building materials to save on future maintenance costs. The payment system rewards the ‘availability’ of roads (NAO, 2002; ODPM, 2004) rather than second-guessing the costs of constructing them. These contracts have durations of many years, often 20 years or more, during which private parties can recoup their investment.

On the other hand, one can recognize ideas in the PPP literature that resemble the arguments presented in the vast literature on (network and collaborative) governance. These streams of literature stress the importance of horizontal coordination between public actors and their partners. They also emphasize that it is difficult or impossible to revert to top-down steering in a network society in which interdependence has increased consequent to processes of specialization, fragmentation, privatization, knowledge distribution, individualization, and rising demands (see Frederickson, 2005; Klijn \& Koppenjan, 2016a; Sørensen \& Torfing, 2007). The governance literature emphasizes the complex nature of decision making and service delivery, dependence on other actors, and the need for (horizontal) collaboration and active forms of network management that promote collaboration between public and private actors, that generate new innovative solutions and the use of knowledge among the actors, and that reduce veto powers and obstruction (see Agranoff and McGuire, 2001; Klijn \& Koppenjan, 2016a). Recently, these ideas have been coined as the New Public Governance (NPG) perspective, often presented as the alternative to, and successor of, the NPM paradigm. NPG is not only of theoretical relevance. It is also a normative perspective that stems from and guides new practices within public administration that have emerged in response to both TPA and NPM (Bryson, Crosby, \& Bloomberg, 2014; Klijn \& Koppenjan, 2016a; Koppenjan \& Koliba, 2013; Osborne, 2006). Some core elements of the discussion on governance are present in the ideas on PPP. These include, for example, the assumption that co-production between public and private actors results in the exchange of more information and the usage of each other's knowledge and thus generates more innovative ideas, better services, and better policy outputs for complex societal problems.

PPP's hybrid character makes it difficult to pin down what PPP as an idea stands for and how collaboration in PPPs actually takes shape. On the one hand, collaboration can be shaped using contracts, performance criteria, and sanctions (the NPM argument), whereas, on the other hand, collaboration in PPPs is governed by focusing on the informal relationships between project partners and includes the building of trust. According to the governance perspective, contracts can never be complete and are not fitted to deal with the complex nature of decision making. We elaborate on both reasonings in the next section. After that, we test both assumptions with some recent empirical research conducted by the authors in a fouryear research project on PPP governance. 


\section{GOVERNANCE MECHANISMS IN PPPS: CONTRACTS VS TRUST AND MANAGEMENT}

As described in the previous section, two main theoretical arguments come from two different perspectives regarding collaboration in PPPs. The literature on (collaborative and network) governance emphasizes horizontal collaboration, management, and the building of trust (see Ansell \& Gash, 2008; Klijn \& Koppenjan, 2016a). The NPM perspective on partnerships suggests a (neo)institutional perspective and views contracts as crucial in realizing collaboration and projects. Buyers and sellers are led by their own rational behavior and are incentivized and constrained by contracts.

\section{Partnership as Risk-Taking and Contractual Safeguards: The Economic Perspective on Partnerships}

From a purely rational economic perspective, in partnerships (and PPPs) there is no need for collaborative activities or the concept of trust, even in more complex situations involving specific investments, uncertainties, and long-term relations. In situations of incomplete contracts (and incomplete information, as most theorists would embrace the idea of bounded rationality), most neo-institutional economists would suggest means other than trust and collaboration to address these uncertainties (see Williamson, 1996). They would stress that incomplete contracts should come with safeguard mechanisms to protect the contractor against other parties (Deakin and Michie, 1997; Nooteboom, 2002). Their solution to the problem of risk would most likely lie in contractual safeguards and reputation-related incentives (see Deakin \& Michie, 1997). Monitoring the contract's performance criteria, and whether thus the partner is abiding by the contract terms, would then be the counterpart of contractual safeguards. These safeguards can take the form of bonds, penalties, and other contractual agreements and should serve to prevent opportunistic behavior and facilitate the resolution of ex-post disputes between partners. Williamson (1996) goes so far as to contend that trust is a confusing concept because it amounts to nothing more than risk-taking. He says that: "calculative relations should be described in calculative terms, to which the language of risk is exactly suited" (Williamson, 1996, pp. 485-486). In his view, notions of trust only blur the argument, because they cause one party to accept the risk that the other party may be acting opportunistically. In his view, the notion of trust as acting in good faith (without calculation) does not add anything useful to the analysis of the situation.

\section{Complexity and the Need for Trust}

However, in contractual relations, in partnerships and other relationships involving private and public actors of various affiliations, actors are confronted with risks and uncertainties that can take various forms. Williamson, in rejecting the role of trust, assumes that these risks can be calculated or at least be taken into account by involved actors, but this assumption cannot be easily squared with the idea of bounded rationality, which is also the starting point in the neo-institutional approach (see Nooteboom, 2002). If the possibility of gathering information is limited, then so are the opportunities to assess the behavioral alternatives that independent actors have in a partnership. Interestingly, this argument holds even more strongly for situations where partnerships contain several actors or are characterized by a network of dedicated and involved actors and when partnerships extend over a long period (Klijn \& Koppenjan, 2016a).

Given the duration of partnership contracts, the complexity of partnerships, and the high level of uncertainty, it is very unlikely that contracts can be the sole instrument used to organize partnerships. There are simply too many unforeseen futures to be specified in the 
contract and too many uncertainties about possible outcomes. This means that partnerships, although they may benefit from contracts, need additional conditions to achieve collaboration and good performance, like extensive relational management and trust building. This actually is the main assumption in the collaborative and network governance literature.

\section{The Importance of Trust, Collaboration, and Management}

Trust is needed to have actors invest in complex collaborations in which risks are involved, but trust cannot be assumed to be present. If it is present, it is vulnerable and needs to be nurtured (Klijn, Edelenbos, \& Steijn, 2010). There are so many uncertainties and unforeseen developments in long-term partnerships that active (network) management is necessary to build trust, enhance collaboration, and reach satisfactory outcomes.

Because of the characteristics of a partnership, whether it is a contractual or a networklike type, network management is considered crucial to achieve coordination of actions and bring together the necessary resources (see also Gage \& Mandell, 1990; Huxham \& Vangen, 2005; Kickert et al., 1997; McGuire \& Agranoff, 2011). There is broad consensus in the literature about networks, collaborative governance, and interactive governance that the type of leadership and management required in networks and partnerships differs significantly both from interorganizational management (aligning internal management functions - such as budgets, personnel, organization - with organizational objectives) and from contract management (in terms of keeping agents to the contract). Ansell and Gash (2008) talk about facilitating leadership; by which they emphasize that the important job of a leader is to mediate between actors and empower the collaboration process. In this literature, the deliberate guidance of complex governance processes is mostly called network management, but it is also referred to as network governance, collaborative governance, or metagovernance (Mandell, 2001; O’Toole, 1988; Sørensen \& Torfing, 2007). Usually, actions are characterized as activating actors, exploring solutions (and connecting perceptions and interests), arranging interactions, and setting up process rules. These management activities include addressing so-called soft dimensions of relationships: motivating actors, listening to their concerns, safeguarding their interests, investing in good relationships and a safe and inspiring collaboration environment, managing conflicts, building trust, and so forth. The assumption here is that, when these (network) management and relational governance strategies are applied, trust is generated, collaboration is enhanced, and eventually better outcomes are achieved than if this is not the case. In the collaborative and network governance perspectives, the importance of contracts, monitoring, and sanctions would thus be greatly downplayed in favor of trust and other relational governance strategies.

\section{Conclusion: Relational Governance Is Necessary for Collaboration}

The theoretical sections have shown that PPP is a hybrid idea that combines various and sometimes contradictory governance ideas and assumptions. The two different perspectives discussed propose very different ways of governing PPP collaboration.

Neo-institutional economics suggests an important role for contracts, strict contract management, including the use of performance indicators, and a clear risk division, whereas the governance perspective suggests trust and relational governance. The empirical research on PPPs has long focused on the different contractual forms of PPP, its promises, and its performance. In short, it has been concerned with questions about what PPPs are and what they can achieve (Hodge \& Greve, 2017). Many of these studies focus on PPPs as a contractual model and a tool designed to effectively realize long-term infrastructural projects (e.g. Hodge et al., 2010). The NPM principles are often clearly reflected in these studies. As 
Wang et al. (2017) show, research on PPP within the public administration discipline has predominantly focused on the concept of PPP, the drivers of PPP adoption by governments, the allocation of risks between public and private partners, and the performance of the partnership. The management of these partnerships has also been the subject of earlier research (see for example Klijn \& Teisman, 2003; Osborne, 2000). However, in the early days of PPP research, there was a lack of attention on relational governance and soft aspects such as trust, informal communication, and commitment. Relatively few scholars studied PPP from a governance perspective in which the relationship between public and private partners was not just a contract-based principal-agent relationship, but rather one in which horizontal principal-principal relationships could be established and soft elements such as trust were potentially crucial governance mechanisms. Reeves, for example, showed in his 2008 study that the relationships between public and private actors in PPPs in the Irish school sector had predominantly a transactional nature rather than a collaborative (trust-based) nature.

Nevertheless, the attention paid to the soft side of these partnerships has been increasing. Several studies have examined the role of trust in these partnerships (e.g. Barretta, Busco, \& Ruggiero, 2008; Brogaard, 2017; Edelenbos \& Klijn, 2007; Panda, 2016; Smyth \& Edkins, 2007). Most of these studies indicate that trust plays an important role in PPPs. With the seemingly important role of both contractual and relational governance, the question arises as to the ratio required between these two governance mechanisms. Can we combine contractual and relational governance within the same PPP project? And how can they be combined?

\section{CONTRACTUAL VERSUS RELATIONAL GOVERNANCE IN PUBLIC-PRIVATE PARTNERSHIPS: WHAT DOES EMPIRICAL RESEARCH TELL US?}

In a large, four-year research project on smartening PPP governance, we examined a number of relevant assumptions about the influence of contractual and relational governance on the collaboration in these partnerships. First, we tested basic assumptions about the importance of contract characteristics and relational elements for PPP performance. Next, we studied PPP professionals' perceptions on the management of collaboration in PPPs. Finally, we made an attempt to show that contractual and relational governance can be combined in PPPs in practice by providing insight into different mixes of both forms of governance in well-performing partnerships.

\section{The Role of Contracts in PPP}

To manage the collaborative effort that is central in PPPs, contracts are - from an NPM perspective - considered to be a crucial governance mechanism. In a survey of the vast majority of PPP projects in the Netherlands, we studied how the different contract characteristics affected the performance of these partnerships (Klijn \& Koppenjan, 2016b). These characteristics were the duration of the contract, the use of sanctions, and the complexity and flexibility of the contract. The duration of the contract was expected to have a positive relationship with PPP performance, as the long term of these contracts allows the private partner to recover its initial investment (Hodge et al., 2010). Moreover, the contracts' long term implied that several project phases (design, build, maintenance) were integrated into the same contract, which allowed for lifecycle optimizations (e.g. NAO, 2002). From the neo-institutionalist economics perspective, the use of sanctions is particularly useful to prevent opportunistic behavior. The complexity of the contract and its flexibility and room for renegotiations are also expected to have an impact on partnership performance. Complex contracts require high transaction costs, making them less effective. Flexibility is often needed in long-term contracts to deal with unforeseen events or allow for renegotiations to 
prevent suboptimal outcomes (Verweij, 2015). A multilevel analysis (MLA) ${ }^{1}$ based on a survey among 144 public and private professionals (response rate of 46.6\%) in 68 PPP projects in the Netherlands showed that these contract characteristics have only limited effect on PPP performance (Klijn \& Koppenjan, 2016b). Neither complexity, flexibility, nor room for negotiation seem significantly related to the performance of these partnerships. Neither does the long duration of these contracts have a significant effect on PPP performance. Contrary to popular NPM beliefs underlying PPPs, the possibility of sanctions does not ensure collaboration between public and private actors. Instead, our results show a significant negative effect $(-.051$, with $\mathrm{p}<.05)$ on PPP performance. Sanctions do not ensure collaboration between project partners, but instead weaken the results of the collaborative effort in PPPs. Thus, although contracts are a core element of the organizational arrangements in PPPs and these results do not imply that contracts in PPPs are useless as a governance mechanism, some doubt is cast on the importance of contracts and specific contract characteristics for PPP performance. Contracts may be important to construct PPPs and as a fallback option when things go wrong, but the influence of formal contracts on good PPP performance seems to be overrated. These findings confirm our theoretical expectations that we need to look beyond contracts to properly understand and manage PPPs and their performance (Klijn \& Koppenjan, 2016b). Other factors, perhaps under different assumptions regarding the collaboration of public and private actors in a PPP, are also important.

\section{Trust and Relational Governance}

The (network) governance literature contends that network management and trust are two of these factors. Trust creates greater predictability, reduces risks associated with opportunistic behavior, and stimulates the sharing of information (Nooteboom, 2002; Bachman \& Zaheer, 2006). Trust can compensate for the uncertainty in partnerships and thus creates a basis for long-term collaboration (Parker \& Vaidya, 2001; Ring \& van der Ven, 1992). Network management activities all focus on strengthening the collaboration between partners. They facilitate interaction between partners, try to enhance coordination, and aim to align the interests of partners in the network (Ansell \& Gash, 2008; Huxham \& Vangen, 2005). Consequently, better collaboration should result in better performance. Our MLA shows that indeed trust is significantly correlated $(\mathrm{p}<.001)$ with collaboration in PPP projects (Warsen et al., 2018). Surprisingly, network management is not. One of the potential explanations here is that the effect between network management and collaboration is merely indirect, as network management also stimulates the building of trust. In turn, trust facilitates collaboration. Analysis of the effect of trust and network management on PPP performance revealed a significant correlation (management: $\mathrm{p}<.01$; trust: $\mathrm{p}<.05$ ). These results demonstrate the relevance of PPPs' collaborative characteristics (Warsen et al., 2018) and call for more research into PPP under governance-based assumptions. Given the complexity of PPPs and their long duration, it is not surprising that collaborative elements are important governance mechanisms in these partnerships. After all, both complexity and the long timeframe make it hard to predict what will happen. Unexpected events will occur, and both trust and network governance are far better suited to deal with these uncertainties than rigid contracts (Warsen et al., 2018).

\footnotetext{
${ }^{1}$ In MLA, variables are analyzed at different levels (organizational, personal, and so on). In this case, as we had sometimes more than one respondent for each project, the variance of our outcomes was partly the result of variables at project rather than individual level, as individual and project levels were analyzed (40\% of the variance of our outcomes was due to differences at project level), thus justifying MLA use. As the professionals working in similar projects might make similar responses, MLA was used to test our hypothesis on two levels both individual and project - and to identify how much of the variation in the scores was attributable to group membership (i.e. to professionals working on the same project).
} 


\section{Practitioners' Perspectives on PPP Governance}

Research shows that relational governance is crucial for the realization of the collaborative efforts in PPPs. In practice, however, most PPP projects use contracts. The governance of these projects is hybrid in nature, and this may be confusing to the parties involved. This raises the question of how public and private professionals working in these partnerships think about the use of both contractual and relational governance in PPPs. What are their perceptions about the governance of PPPs? With partners coming from different institutional backgrounds and with different interests, PPPs need to be governed to ensure the project's progress (Warsen et al., 2020). To examine this question, we conducted a study using Q-methodology. ${ }^{2}$ Based on 24 statements on different forms of management (from well-known governance paradigms in public administration such as Traditional Public Administration (TPA), New Public Management (NPM), New Public Governance (NPG), and self-organization), the study provides crucial insights into the perceptions of 119 PPP professionals from Denmark, the Netherlands, and Canada. Four different profiles regarding the governance of PPP can be distinguished (see table 2).

Table 2. Four profiles on governing PPPs

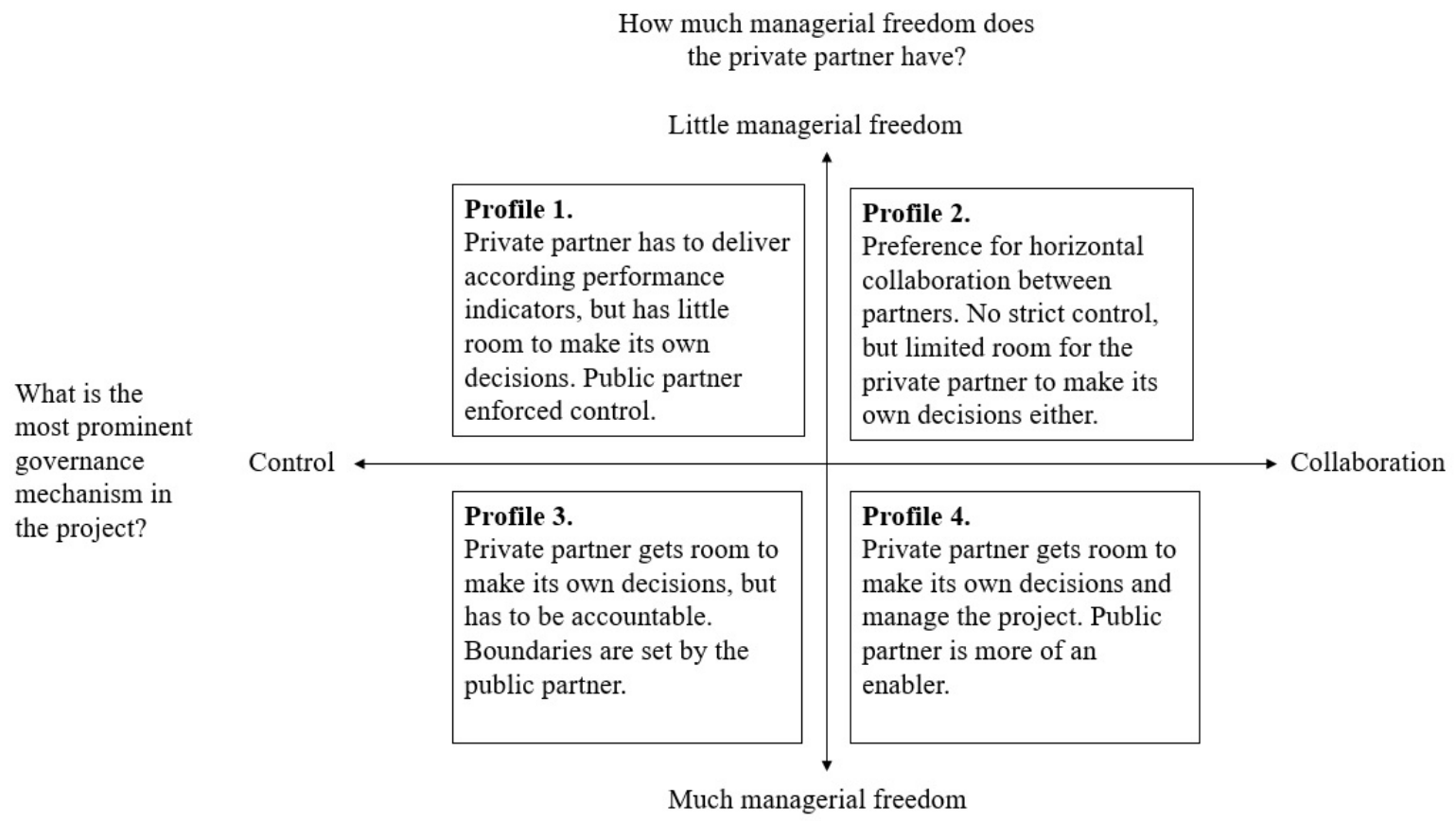

Practitioners' opinions regarding PPP governance and design are not aligned. Some value a more performance and contract-based approach, whereas others opt for a strong focus on horizontal collaboration. For each of the four different perspectives, a mix of professionals from different countries, with different backgrounds and different levels of experience, adhere to the governance ideas presented in the perspective (Warsen et al., 2020). The first perspective clearly resembles the ideas of NPM and advocates contractual governance as the main governance mechanism. The relationship between the public and the private partner can be considered a principal-agent relationship, in which the principal tries to prevent opportunistic behavior by the agent. Professionals that share the second perspective have a preference for horizontal collaboration between project partners as the most prominent governance mechanism (NPG inspired). The third perspective held among PPP practitioners

\footnotetext{
${ }^{2}$ Q-methodology identifies people’s perceptions and uses a factor analysis to identify patterns in the way in which these perceptions correlate.
} 
is the opposite to the second perspective and focuses on the balance between the expertise of the private partner and the need for accountability to the public partner. This profile combines control (TPA and NPM elements) as the most prominent governance mechanism in the project with a relatively high degree of managerial freedom for the private partner (selforganization). The fourth perspective expressed among PPP practitioners is based upon horizontal collaboration, trust, and managerial freedom as the main governance mechanisms. This perspective is predominantly self-organization oriented, with some governance elements (Warsen et al., 2020).

These governance ideas of practitioners are of a hybrid nature, combining features of various theoretical paradigms. Moreover, as the study clearly shows, there are diverging perceptions about governing PPPs. Each of the four perspectives differs, and each attracts a varied audience of practitioners, from different countries and working for different aspects of the project. However, an additional regression analysis shows that country, level of experience, and the public/private distinction can make a difference for professionals' viewpoints. Some perspectives are more dominant in one country than in another. The Canadian professionals, for example, are more often associated with the first profile, in which performance indicators and the enforcement of the contract by public partners are valued most. The Dutch professionals are, in contrast, significantly more likely to adhere to the second perspective $(\mathrm{p}<.001)$, which aligns with the strong Dutch administrative tradition of compromise and horizontal working relationships. Finally, the viewpoints represented by the fourth perspective can be found significantly more often among Danish practitioners ( $\mathrm{p}<$ .01). The different administrative traditions and experiences with PPP might explain these differences. Danish (local) governments, for example, are not frequent users of PPPs, and this makes them relatively inexperienced compared to the private sector and perhaps therefore more inclined to give room to the private partner regarding the realization of the project (Warsen et al., 2020). It might not come as a surprise that there are also some differences in the viewpoints of public and private professionals regarding PPP governance. Although both can be found in all four profiles, the study indicates that private partners are more positive about the perspectives that emphasize horizontal collaboration (perspective 2, $\mathrm{p}<.05$; and perspective $4, \mathrm{p}<.01$ ). Compared with public professionals, they are less likely to adhere to the ideas from perspective 1 on performance indicators and control (Warsen et al., 2019). As they are working for the agent in the principal-agent relationship, these indicators provide strict boundaries within which they should work and limit their autonomy to act. Finally, experience seems to have an impact on professionals' perceptions, in particular with regard to the autonomy of the private partner. Experienced professionals are more positive about the fourth perspective $(\mathrm{p}<.05)$ in which the private actor's behavior is not enforced via strict contracts; rather, the private actor is allowed a high degree of managerial freedom (Warsen et al., 2020).

\section{Getting the Right Mix for PPP: Contractual and Relational Governance}

Professionals' hybrid perceptions regarding PPP governance encourage further research into the hybridity of governing the collaborative efforts underlying these partnerships. Given the hybrid ideas underlying PPPs and PPP governance, how can we achieve collaboration in these partnerships? Can we merge these diverging perceptions in a mix of different governance mechanisms? Several studied propose the idea that PPPs might benefit from a mix of contractual and relational governance (e.g. Brown, Potoski, \& van Slyke, 2016; Edelenbos \& Eshuis, 2012; Parker \& Hartley, 2003; Poppo \& Zenger, 2002). Whereas the contract provides clarity regarding the tasks, roles, and responsibilities of both partners, relational governance provides some room for flexibility in the event of 
circumstances changing. The question remains as to which mix of contractual and relational governance mechanisms might contribute to the success of PPPs. Using a fuzzy set Qualitative Comparative Analysis ${ }^{3}$ of 25 PPP projects in the Netherlands and Flanders (Belgium), we identified several mixes of conditions that are present in highly successful PPP projects (Warsen et al., 2019). The contractual elements in our study were the allocation of risks and the strict application of sanctions, whereas trust and conflict management were considered relational elements. Each of these paths is discussed briefly below.

The first mix of contractual and relational governance mechanisms in successful PPPs is the combination of high levels of trust combined with good risk allocation. The allocation of risks might provide clarity as to the tasks and responsibilities of each actor. As the allocation of risks is determined in the early phases of the process, trust can then be used to manage the project in the later stages and help partners to continue collaborating when the allocation of risks needs to be altered. The second mix combines the allocation of risks with conflict management and the strict application of sanctions. All three conditions here point toward the importance of clear agreements. The allocation of risks comprises agreements regarding tasks and responsibilities, whereas the sanctions are agreements regarding the enforcement of the contract. Conflict management includes (informal) agreements regarding the prevention, control, and resolution of disagreements and conflicts. These agreements help to ensure a good collaborative process and might thus lead to good performance. The final mix consists of a combination of two relational elements, namely trust and conflict management. Surprisingly, this mix explicitly includes the absence of a strict application of sanctions as a condition. This path is in line with the theories on collaborative governance and suggests that contractual elements are not necessary to prevent opportunistic behavior (Warsen et al., 2019).

\section{REFLECTION: HYBRIDITY AND BALANCING CONTRACTS AND COLLABORATIVE PUBLIC MANAGEMENT}

In this contribution, we have examined the hybrid nature of the governance of PPP collaboration. First of all, we stated that PPPs as hybrid arrangements provide challenges to arrive at collaboration between public and private actors - hence the importance of the governance of PPP collaboration. However, theories on PPP governance are hybrid themselves, mixing elements of various governance approaches, more specifically ideas from the NPM and governance perspectives. Focusing on contractual PPPs and in particular DBFM contracts, we have shown that ideas on the role of contracts are complemented with the acknowledgement that the complex nature of projects governed by DBFM contracts, and the long and enduring relationships that they imply, require additional governance mechanisms like trust and relational governance. This gives rise to the question of how this hybridity can be dealt with: how these elements relate to each other and what mixes enhance collaboration and performance.

\footnotetext{
${ }^{3}$ QCA is a method that assumes that "the effect of a single condition unfolds only in combination with other conditions” (Schneider \& Wagemann, 2012, p. 78). This means that performance is explained not by a single condition, but by a combination of conditions. Furthermore, another underlying principle of this method is that an outcome, such as performance, can be achieved through multiple paths (Schneider \& Wagemann, 2012). Just as with the proverbial city of Rome, various combinations of conditions may result in the same outcome. The particular characteristics of this method allow one to study combinations of various governance mechanisms to see which combinations are present in successful PPPs and how contractual and relational (collaborative?) governance mechanisms can be combined.
} 
The results of the empirical studies discussed confirm that contracts alone do not generate good partnership performance. Only if combined with more relational governance elements can contracts have positive impacts.

Our research also shows that practitioners' governance ideas are of a hybrid nature, combining features of various theoretical paradigms. What is more, among themselves, practitioners have diverging perceptions about managing PPPs, resulting in diverging expectations and misinterpretations, thus contributing to the hybrid nature of PPPs' collaborative governance practices in a negative sense.

In addition, our studies shed light on the hybrid nature of governance attempts underlying successful PPPs. Successful PPPs always included at least one of the relational governance elements, whether that was trust or conflict management. This highlights the importance of relational governance, even within contract-based PPPs. In two of the three mixes, these collaborative conditions were combined with risk allocation as the contractual element. These mixes are in line with previous studies that argue that collaborative and contractual governance are mutually complementary (e.g. Edelenbos \& Eshuis, 2012; Poppo \& Zenger, 2002). As the theory of incomplete contracting suggests, a contract cannot cover all potential events and circumstances, especially not in the complex and long-term projects that characterize PPPs. Relational governance is needed to successfully manage uncertainties in a project. So, to make collaborative efforts in PPPs successful, it is the mix that matters. Besides the presence of a contract, project partners should invest in relational governance mechanisms, such as trust and good conflict management.

This means that, in our further theorizing of PPPs, we have to pay much more attention not only to relational governance but also to the hybridity that characterizes the governance of PPP collaboration: the interplay of contractual characteristics and stricter forms of contract management with relational governance and the building of trust. Our QCA identified three specific pathways that mixed these elements in a particular way. However, as this research was limited in scope, future research should investigate the implications and potentials of various mixes in greater depth (to increase our understanding of the hybrid mechanisms at play) and in a more quantitative way (to ascertain the generalizability of our findings), beyond the specific context of Dutch DBFM projects, widening the scope to other PPP arrangements and to other countries.

\section{REFERENCES}

Agranoff, R., \& McGuire, M. (2001). Big questions in public network management research. Journal of Public Administration Research and Theory, 11(3), 295-326.

Ansell, C., \& Gash, A. (2008). Collaborative governance in theory and practice. Journal of Public Administration Research and Theory, 18(4), 543-571.

Bachman, R., \& Zaheer, A. (Eds.). (2006). Handbook of trust research. Cheltenham: Edward Elgar.

Barretta, A., Busco, C., \& Ruggiero, P. (2008). Trust in project financing: An Italian health care example. Public Money and Management, 28(3), 179-184.

Brogaard, L. (2017). The impact of innovation training on successful outcomes in publicprivate partnerships. Public Management Review, 19(8), 1184-1205.

Brown, T. L., Potoski, M., \& van Slyke, D. M. (2016). Managing complex contracts: A theoretical approach. Journal of Public Administration Research and Theory, 26(2), 294308. 
Bryson, J. M., Crosby, B. C., \& Bloomberg, L. (2014). Public value governance: Moving beyond traditional public administration and the new public management. Public Administration Review, 74(4), 445-456.

Deakin, S., \& Michie, J. (Eds.). (1997). Contract, co-operation, and competition: Studies in economics, management and law. Oxford: Oxford University Press

Edelenbos, J., \& Eshuis, J. (2012). The interplay between trust and control in governance processes: A conceptual and empirical investigation. Administration \& Society, 44(6), 647-674.

Edelenbos, J., \& Klijn, E-H. (2007). Trust in complex decision-making networks: A theoretical and empirical exploration. Administration \& Society, 39(1), 25-50.

Frederickson, H. G. (2005). What happened to public administration? Governance, governance everywhere. In E. Ferlie, L. Lynn, \& C. Pollitt (Eds.), The Oxford handbook of public management (pp. 281-304). Oxford: Oxford University Press.

Gage, R. W., \& Mandell, M. P. (Eds.). (1990). Strategies for managing intergovernmental policies and networks. New York: Preager.

Ghobadian, A., Gallear, D., O’Regan, N., \& Viney, H. (Eds.). (2004). Public-private partnerships: Policy and experience. Basingstoke: Palgrave.

Greve, C. (2007). Recent insights into the performance of public-private partnerships in an international perspective. Tidskrifted Politik, 10(3), 73-82.

Hodge, G., \& Greve, C. (2005). The challenge of public-private partnerships. Cheltenham: Edward Elgar.

Hodge G. A., \& Greve, C. (2017). On public-private performance: A contemporary review. Public Works Management \& Policy, 22(1), 55-78.

Hodge, G., Greve, C., \& Boardman, A. (2010). International handbook on public-private partnerships. Cheltenham: Edward Elgar.

Hood, C. (1991). A public management for all seasons. Public Administration, 69(Spring), 319.

Hughes, O. E. (2012). Public management and administration: An introduction (4th $\mathrm{ed})$. Basingstoke: Palgrave Macmillan.

Huxham, C., \& Vangen, S. (2005). Managing to collaborate: The theory and practice of collaborative advantage. London: Routledge

Jacobs, J. (1992). Systems of survival. London: Random House.

Keast, R., Brown, K., \& Mandell, M. (2007). Getting the right mix: Unpacking integration meanings and strategies. International Public Management Journal, 10(1), 9-33.

Kickert, W. J. M., Klijn, E-H., \& Koppenjan, J. F. M. (Eds.). (1997). Managing complex networks: Strategies for the public sector. London: Sage.

Klijn, E-H. (2010). Public-private partnerships: Deciphering meaning, message and phenomenon. In G. Hodge, C. Greve, \& Boardman (Eds.), International handbook on public-private partnerships (pp. 68-80). Cheltenham: Edward Elgar.

Klijn, E-H., Edelenbos, J., \& Steijn, B. (2010). Trust in governance networks: Its impact and outcomes. Administration \& Society, 42(2), 193-221.

Klijn, E-H., \& Koppenjan, J. F. M. (2016a). Governance networks in the public sector. London: Routledge

Klijn, E-H., \& Koppenjan, J. F. M. (2016b). The impact of contract characteristics on the performance of public-private partnerships (PPPs). Public Money \& Management, 36(6), 455-462.

Klijn, E-H., \& Teisman, G. R. (2003). Institutional and strategic barriers to public-private partnership: An analysis of Dutch cases. Public Money and Management, 23(3), 137-146. 
Koppenjan, J., \& Koliba, C. (2013). Transformations towards New Public Governance: Can the new paradigm handle complexity? International Review of Public Administration, 18(2), 1-8.

Kort, M., \& Klijn, E-H. (2011). Public private partnerships in urban renewal: Organizational form or managerial capacity. Public Administration Review, 71(4), 618-626.

Mandell, M. P. (Ed.). (2001). Getting results through collaboration: Networks and network structures for public policy and management. Westport: Quorum Books.

McGuire, M., \& Agranoff, R. (2011). The limitations of public management networks. Public Administration, 89(2), 265-284.

NAO. (2002). Managing the relationship to secure a successful partnership in PFI projects. London: NAO.

Nooteboom, B. (2002). Trust: Forms, foundations, functions, failures and figures. Cheltenham: Edward Elgar.

ODPM. (2004). Urban regeneration companies - Guidance and qualification criteria. London: Office of the Deputy Prime Minister.

Osborne, D., \& Gaebler, T. (1992). Re-inventing government: How the entrepreneurial spirit is transforming the public sector. Reading, MA: Addison-Wesley

Osborne, S. P. (Ed.). (2000). Public-private partnerships: Theory and practice in international perspective. London: Routledge.

Osborne, S. P. (2006). The New Public Governance. Public Management Review, 8(3), 377387.

O'Toole Jr., L. J. (1988). Strategies for intergovernmental management: Implementing programs in interorganizational networks. International Journal of Public Administration, 11(4), 417-441.

Panda, D. K. (2016). Public-private partnerships and value creation: The role of relationship dynamics. International Journal of Organizational Analysis, 24(1), 162-183.

Parker, D., \& Hartley, K. (2003). Transaction costs, relational contracting and public private partnerships: A case study of UK defence. Journal of Purchasing and Supply Management, 9(3), 97-108.

Parker, D., \& Vaidya, K. (2001). An economic perspective on innovation networks. In O. Jones, S. Conway, \& F. Steward (Eds.), Social interaction and organisational change: Aston perspectives on innovation networks. London: Imperial College Press.

Poppo, L., \& Zenger, T. (2002). Do formal contracts and relational governance function as substitutes or complements? Strategic Management Journal, 23(8), 707-725.

Reeves, E. (2008). The practice of contracting in public private partnerships: Transaction costs and relational contracting in the Irish schools sector. Public Administration, 86(4), 969-986.

Ring, P. S., \& Van der Ven, A. (1992). Structuring cooperative relations between organizations. Strategic Management Journal, 13(7), 483-498.

Savas, E. S. (2000). Privatization and public-private partnerships. New York: Seven Bridges.

Schneider, C. Q., \& Wagemann, C. (2012). Set-theoretic methods for the social sciences: A guide to qualitative comparative analysis. Cambridge, UK: Cambridge University Press.

Smyth, H., \& Edkins, A. (2007). Relationship management in the management of PFI/PPP projects in the UK. International Journal of Project Management, 25(3), 232-240.

Sørenson, E., \& Torfing, J. (Eds.). (2007). Theories of democratic network governance. Cheltenham: Edward Elgar.

Verweij, S. (2015). Once the shovel hits the ground: Evaluating the management of complex implementation processes of public-private partnership infrastructure projects with qualitative comparative analysis. Doctoral thesis. Rotterdam: Erasmus University Rotterdam. 
Wang, H., Xiong, W., Wu, G., \& Zhu, D. (2017). Public-private partnership in public administration discipline: A literature review. Public Management Review, 20(2), 293316.

Warsen, R., Greve, C., Klijn, E-H., Koppenjan, J. F. M., \& Siemiatycki, M. (2020). How do professionals perceive the governance of public-private partnership? Evidence from Canada, the Netherlands and Denmark. Public Administration 98: 124-139

Warsen, R., Klijn, E-H., \& Koppenjan, J. F. M. (2019). Mix and match: How contractual and relational conditions are combined in successful public-private partnerships. Journal of Public Administration and Theory, 29(3), 375-393.

Warsen, R., Nederhand, J., Klijn, E-H., Grotenbreg, S., \& Koppenjan, J. F. M. (2018). What makes public-private partnerships work? Survey research into the outcomes and the quality of cooperation in PPPs. Public Management Review, 20(8), 1165-1185.

Weihe, G. (2008). Ordering disorder: On the perplexities of the partnership literature. The Australian Journal of Public Administration, 67(4), 430-442.

Williamson, O. E. (1996). The mechanisms of governance. London: Oxford University Press. 